\title{
DISINTEGRASI, PEMERINTAHAN LOKAL DAN DANA PERIMBANGAN PUSAT DAN DAERAH
}

\author{
Pandji Santosa \\ Dosen Jurusan Ilmu Pemerintahan FISIP Unla \\ Jl. Karapitan no. 116 Bandung \\ email: panz_oxeh@yahoo.com
}

\begin{abstract}
ABSTRAK. Peraturan tentang perimbangan keuangan pusat dan daerah ini titik beratnya masih pada pembagian proporsi bukan pada pemberian kewenangan yang luas dalam pengelolaan sumberdaya. Penekanan lebih besar pada bagi hasil sumberdaya alam (SDA) dinilai lebih menguntungkan daerah yang kaya dan tidak menguntungkan daerah bukan penghasil kekayaan alam. Sumber dana alokasi umum, meskipun didasarkan formula yang lebih objektif dan transparan, tetapi cenderung mengutamakan pemerataan dan kurang memperhatikan sisi keadilan. Keberhasilan pemerintah untuk mengatasai masalah keuangan daerah sebenarnya merupakan langkah penting dalam menggerakkan roda pemerintahan di daerah, tetapi dampak yang ditimbulkannya akan berpotensi kepada tuntutan pembagian keuangan yang lebih tepat, tuntutan federalisasi, sampai ke ancaman disintegrasi ketika pemerintah pusat dinilai mempertahankan perimbangan keuangan pusatdaerah secara tidak adil karena tidak memperhitungkan kontribusi daerah kepada pendapatan pusat. Untuk mengantisipasi munculnya dampak negatif di atas maka setiap desain perimbangan keuangan selain perlu dirancang lebih cermat dan memperhitungkan pemerataan daerah juga hendaknya kebijakan dana perimbangan pusat dengan daerah senantiasa bersendikan elemen potensi kapasitas penerimaan daerah, kontribusi daerah kepada pendapatan pusat, serta menjamin otonomi daerah dan akuntabilitas lokal.
\end{abstract}

Kata kunci: Disintegrasi, Pemerintahan Lokal dan Kebijakan Dana Perimbangan Pusat dengan daerah.

\section{DISINTEGRATION, LOCAL GOVERNANCE AND PROPORTION FUNDING CENTRAL AND RURAL}

ABSTRACT. The rule of proportion funding central and rural financial are still based on proportional apportion, and not by wide span of authority delegation to resources manajement. In that condition, the necessitation on natural resources share out are consider more propitious for the wealthier rural and inauspicious for any rural that does not have any natural resources. The allocation on general funding are based on objective and transparent formula, but still using equal apportion and not considering the equity side of the rural. The government ability to overcome rural funding difficulty is the most important movement in governing 
the rural area, but the consequences will lead to the demand on the funding apportion, federalization, even to the disintegration threat, when the central government are consider cannot maintain the fairness on proportional apportion between central and rural government, because it does not consider the rural contribution to central government revenue. Designing the appropriate and based on the assessment on the equity of rural the funding, implemented the right funding apportion policy that based on rural area revenue capability, and also guarantee on rural autonomy and the local accountability, are ways to anticipate the negative effect caused by the funding apportion.

Keyword: Disintegration, Local Governance and Proportion Funding Central and Rural.

\section{PENDAHULUAN}

Indonesia, selain dituntut agar segera keluar dari krisis ekonomi saat ini menghadapi beragam tuntutan dari daerah baik yang menyangkut tuntutan otonomi luas, otonomi khusus sampai kepada tuntutan pembagian keuangan yang lebih adil, tuntutan federalisasi hingga terdapat juga tuntutan kemerdekaan. Kebijakan pemerintah pusat yang dianggap tidak adil oleh masyarakatnya di daerah pada waktu tertentu dianggap masalah dan menimbulkan kritik karena selain hasil pembangunannya dianggap tidak memuaskan masyarakat juga dampak dari pembangunannya dapat memperparah kesenjangan sosial. Kritisi terhadap ketidakadilan yang dinterpretasi bersifat hubungan interpersonal dan perbandingan antardaerah (Mahi, 2000), kemudian menimbulkan dugaan bahwa distribusi pendapatan antar individu atau kelompok anggota masyarakat relatif belum tercapai secara adil dan merata antar daerah dalam lingkup nasional.

Keadaan ini dalam pelaksanaannya baik berdasarkan perspektif teknologi, pertumbuhan, dan kemajuan tidak melahirkan kesejahteraan masyarakat, sehingga situasi ini memberi peluang besar bagi munculnya ancaman yang melemahkan eksistensi negara dan bangsa Indonesia sebagai negara kesatuan dalam ideologi, politik, sosial, budaya, pertahanan serta keamanan dan dapat berkembang menjadi gerakan disintegrasi negara dan bangsa. Ancaman terbesar bagi integrasi nasional cenderung datang dari akumulasi kekecewaan daerah terhadap pusat, atau konflik yang bersifat vertikal. Munculnya bibit-bibit disintegrasi bangsa terjadi antara lain ketika pemerintah pusat dinilai mempertahankan perimbangan keuangan pusat-daerah secara tidak adil dan menimbulkan ketergantungan.

Pemberlakuan otonomi daerah yang dapat menimbulkan distorsi dan biaya ekonomi tinggi pada pasca reformasi perlu segera diatasi sejalan dengan transisi demokrasi lokal yang saat ini sedang melakukan konsolidasi politik agar proses desentralisasi membawa perubahan pada tatanan ekonomi daerah untuk mengembangkan dan memobilisasi PADnya. Setelah pilkada dilaksanakan, maka pelaksanaan demokrasi dan otonomi suatu pemerintah daerah telah memberikan 
kewenangan membuat keputusan maupun kewenangan keuangan yang semakin besar melalui proses politik khas lokal di daerahnya. Dalam kondisi tersebut proses demokratisasi dan politik lokal muncul di daerah disertai dengan peran elitnya yang secara intensif berkembang dengan dinamika sosial politiknya.

Seharusnya sesuai konteks undang-undang, berdasarkan UU No. 22/1999 dan UU No.25/1999 adalah untuk memberdayakan dan meningkatkan kemampuan perekonomian daerah (Hardjosoekarto, 2002:9) yang kini di ubah dengan UU No.32 Tahun 2004 dan UU No. 33 Tahun 2004, namun intinya misi yang dikandung belum bergeser dari undang-undang sebelumnya. Padahal mengatur mobilisasi pendapatan daerah tidak sekedar berorientasi pada kepentingan memaksimalkan pendapatan daerah, tetapi lebih kepada kepentingan mendukung pemberdayaan dan penciptaan ruang yang lebih besar bagi peran serta masyarakat dan stakeholder dalam pengembangan ekonomi daerah. Sehingga konsekuensinya pelimpahan tanggungjawab seharusnya mendorong pengaturan pembagian, pemanfaatan dan sumber daya nasional yang berkeadilan serta perimbangan keuangan pusat dan daerah (Mardiasmo, 2002). Menurut jalan pikiran ini, hubungan keuangan pusat daerah sebagaimana menurut Devas dkk (1989) harus dapat memungkinkan pembagian kekuasaan antara pemerintah pusat dan pemerintah daerah, sehingga tiap-tiap tingkat memiliki lingkup pilihan sendiri-sendiri.

Berdasarkan realitas tersebut masalah penting untuk dikaji adalah bagaimana perilaku politik (Pemerintah Pusat) dapat menghargai aspirasi daerah atau bagaimana agar kebijakan dana perimbangan pusat dapat dipadukan (matching) dengan penguatan demokrasi lokal.

Tulisan ini mencoba mengungkapkan beberapa prespektif dan argumentasi dengan pendekatan pengulasan dan telaahan kritis (review article) terhadap masalah yang dihadapi berdasarkan tinjauan teori administrasi publik, sehingga pembahasan yang diungkapkannya dapat menjelaskan dan membandingkan beberapa penafsiran dan solusi yang sesuai dengan keadaan dan masalah yang dihadapi. Secara umum sasaran penulisan pada intinya berupaya untuk mengeloborasi masalah atau isu yang berkembang dari tiga sudut pandang antara disintegrasi, pemerintahan lokal kebijakan dana perimbangan pusat yang bertujuan mengembangkan demokrasi di aras lokal, sehingga kemampuan dan pemberdayaan ekonomi daerah bisa segera diwujudkan untuk mempercepat kesejahteraan masyarakatnya.

\section{DISINTEGRASI}

Proses demokratisasi yang bertumpu pada otonomi daerah ternyata tidak selalu berjalan mulus dan menyisakan sejumlah persoalan-persoalan baru. Selain munculnya raja-raja kecil di daerah, proliferasi korupsi di daerah, perebutan sumber daya, sentimen putra daerah dan non putra daerah dalam kontelasi politik lokal, muncul berbagai organisasi masa (ormas) yang mengusung sentimen identitas lokal. Hal ini sempat menyulut konfliks kekerasan di banyak daerah yang 
disebabkan oleh tokoh etnis lokal yang bersaing memperebutkan kekuasaan politik dan akses terhadap sumber daya materil (Klinken, 2001).

Hingga kini masih adanya simpul yang menterminologi putra daerah kerap diintrepretasikan secara longgar dan tidak bijak serta tidak hanya mengacu kepada aspek etnisitas, melainkan juga kepada domisili dan tempat kelahiran untuk memberikan ruang bagi tampilnya elit nasional yang mengincar posisi strategis di daerah.

Bila dicermati, adanya konfliks kekerasan di Indonesia bukanlah hal yang baru dalam episode sejarah nasional. Dinamika konflik kekerasan selalu mengiringi perjalan bangsa ini. Karenanya, Indonesianis seperti Ben Anderson tak segansegan berpendapat bahwa kultur kekerasan bukanlah monopoli penguasa orde baru, tetapi sudah sejak lama melekat semua lapisan masyarakat (Anderson, 2001). Namun demikian, dahsyatnya tingkat konflik dan kekerasan atas nama agama, kepentingan etnis dan kelompok di berbagai pelosok negeri serta isu disintegrasi menuntut penjelasan yang lebih luas ketimbang sekedar faktor kultural ataupun dampak dari euphoria politik dari proses demokratisasi.

Di era orde baru, ancaman terbesar bagi integrasi nasional cenderung datang dari akumulasi kekecewaan daerah terhadap pusat, atau konflik yang bersifat vertikal, maka dewasa ini, kekerasan dan konflik horizontal menjelma menjadi ancaman serius bagi integrasi nasional. Ted Gurr, seorang ilmuwan yang mendalami masalah konflik etnis-agama menyimpulkan bahwa sentimen identitas suatu kelompok dapat mengalami pasang surut, sesuai dengan derajat kepentingan anggota suatu kelompok (Gurr, 1993).

Identitas kolektif akan menguat secara drastis manakala kelompok tersebut mengalami diskriminasi dan ketidakadilan. Sebaliknya, identitas kolektif suatu kelompok akan melemah ketika terjadi proses asimilasi atau keanggotaan yang berlapis dari anggota suatu kelompok dengan kelompok-kelompok lain di masyarakat. Namun demikian, pada kasus negara - negara demokrasi baru, kerapkali para pemimpin kelompoklah yang memanipulasi pasang surut identitas kelompoknya. Para pemimpin tersebut mengeksploitasi faktor sejarah clan simbolsimbol kultural untuk memobilisasi dukungan politik.

Menariknya, Samuel Huntington menyatakan bahwa krisis identitas ini bukan saja monopoli negara-negara demokrasi baru, melainkan telah menjadi fenomena global dan melanda negara-negara demokrasi mapan. Merosotnya otoritas negara sebagai penjamin keamanan rakyatnya telah memberikan insentif bagi rakyat untuk menolak mengidentifikasikan diri dengan negara dan mempromosikan identitas kelompok yang bersifat sub nasional maupun trans nasional (Huntington, 2004). Di berbagai belahan dunia tumbuh gerakan - gerakan yang kuat yang berusaha untuk melakukan proses redefinisi identitas negara dalam terminologi keagamaan sebagai upaya adaptasi dengan perubahan pada tataran global dan membangun rasa aman dan nyaman. Menurut Huntington, jika pada abad ke 19 dan 20 para elit politik dan intelektual memobilisasi kebangkitan identitas nasional dan memelopori gerakan-gerakan nasionalisme, saat ini justru kita menyaksikan 
manuver para elit yang tengah melakukan proses denasionalisasi di banyak negara.

Dalam konteks di Indonesia, manuver elit untuk memanipulasi identitas kultural adalah gerakan pemekaran daerah yang marak dilakukan sejak lahirnya Undang-undang nomor 22 tahun 1999 tentang Pemerintahan Daerah. Elit politik lokal, birokrat lokal dan pengusaha lokal memainkan peran penting dalam mengolah emosi masa untuk menciptakan kesadaran kolektif mengenai urgensi dari pembentukan wilayah adminsitratif baru di daerah kelahiran mereka sejak kurun waktu 1999 hingga 2004.

Bagaimana agar segera keluar dari konflikasi dalam permasalahan yang menyangkut konflik dan integrasi nasional? Setidaknya diperlukan penelisikan sisi lain dari konfliks, sebagaimana dikatakan Dahrendorf bahwa konfliks juga dapat dilihat sebagai mekanisme alamiah dalam konteks rekonstruksi sosial untuk mencari keseimbangan baru dan menghilangkan unsur-unsur disintegratif dalam masyarakat. Karenanya, jika mengacu kepada sisi tersebut 1) cara melakukan proses transformasi konflik, yaitu menyalurkan energi negatif konflik kepada saluran-saluran alternatif yang akan mengelola konflik tersebut. 2) Dalam mengatasinya antara konflik kekerasan dan integrasi nasional, politik identitas dan konsolidasi demokrasi, diperlukan komitmen politik dari para elit politik untuk memulai suatu proyek jangka panjang, merumuskan mengenai strategi dan taktik proses nation building untuk membangun kultur baru bangsa yang mengapresiasi perbedaan sebagai modal sosial dan mencetak generasi baru di masa datang.

\section{PEMERINTAHAN LOKAL}

Politik lokal menurut Surbakti (1992) yaitu: (a) Usaha yang di tempuh warga negara untuk mengatasi masalah yang dihadapi masyarakatnya di daerah tertentu; (b) Segala hal yang berkaitan dengan penyelenggaraan negara dan pemerintahan; (c) Segala kegiatan yang diarahkan untuk mencari dan mempertahankan kekuasaan dalam masyarakat; (d) Kegiatan yang berkaiatan dengan perumusan dan pelaksanaan kebijakan umum; (e) Sebagai konflik dalam rangka mencari atau mempertahankan sumber yang dinilai penting. Selain itu ada yang didefinisikan Heinelt dan Wollmann (2003) sebagai suatu sense dalam pembagunan yang secara sosial bentuknya dapat berupa keputusan-keputusan dalam sistem interaksi yang menyangkut fisik dan ruang sosial.

Memahami bagaimana itu politik lokal tentunya akan terkait dengan kekuasaan yang digunakan untuk memimpin suatu masyarakat tertentu. Artinya, kekuasaan itu tidak hanya berdasarkan pada kemampuan tetapi juga ditentukan oleh faktor lain yang memiliki hubungan dengan kondisi daerah bersangkutan. Sebab itu, ada dua faktor yang akan mempengaruhi kehidupan politik lokal dalam masyarakat Indonesia yaitu 1) sistem kultural dan 2) kepercayaan (Sjamsudin, 1989).

Namun yang perlu diperhatikan dalam konteks politik lokal ini adalah bagaimana memadukan antara keinginan pusat dan aspirasi lokal yang muncul di 
daerah yang tidak lepas dari peran birokrasi pada aras lokal. Sebab dinamika kehidupan pemerintahan lokal yang akan dibangun tersebut, kondisinya akan terus berubah oleh pengaruh perubahan konteks ekonomi dan sosial, selain oleh konfliks ideologi dan politik lokal yang terjadi disekitar pemerintahan lokal (John and Gerry, 1989).

Perlu juga dipahami bahwa aras pemerintahan lokal tersebut memiliki karateristik yang berbeda di setiap daerah sehingga diperlukan penyesuaian dengan pemerintah pusat. Di samping itu, diperlukan pula perubahan struktur pemerintahan lokal yang akan berdampak pada perubahan perluasan program ekonomi, sosial, dan pembaharuan ideologi.

Boleh jadi, upaya yang perlu dilakukan adalah menghadapi tantangan yang ditekankan pada keuangan untuk kemudian diperluas perhatiannya pada peran, organisasi, kelembagaan, dan manajemen. Oleh karena itu, dalam pemerintahan lokal penataan kehidupan bernegara untuk melakukan interaksi dengan pemerintah pusat secara optimal perlu dilakukan. Untuk itu, beberapa hal yang hendaknya dikaji dalam mewujudkan good local governance yaitu: pengelolaan SDM, pengelolaan keuangan, pengelolaan sarana dan prasarana, serta prosedur kerja (hubungan kerja, koordinasi). Tidak ketinggalan upaya penyempurnaan proses perencanaan, pengorganisasian, pelaksanaan, pengawasan dan pengendalian (Santosa, 2008:138).

Semua itu, diperlukan guna memberikan arti bernegara bahwa kehidupan tradisional sudah mulai disinergiskan dengan aktivitas yang mengarah kepada kepentingan nasional di era globalisasi, sehingga mau tak mau, suka atau tak suka telah masuk ke dalam arena globalisasi, berhenti sedikit saja akan tergerus arus tersebut. Artinya, dalam program pembangunan lokal maupun nasional harus diintegrasikan, kemudian harus berdampak pada stabilitas internal. Hal ini, tentunya memerlukan peran dari pemerintah pusat, dan pada saat yang sama peran pemerintah daerah (propinsi ataupun kabupaten dan kota) sangat dibutuhkan. Karena kurangnya sumber yang tersedia ditingkat lokal, maka pemerintah lokal pada saat ini mendapat peran penting dan akses dari struktur pemerintah pusat.

Semua itu, dapat diwujudkan melalui kebijakan pemerintah pusat yang akan didesentralisasikan pada pemerintah lokal yang merupakan otoritas daerah untuk menyatukan berbagai kepentingan, tujuan dan kemampuan dalam pembangunan daerah melalui program pembangunan. Sehingga dalam pelaksanaan desentralisasi dan otonomi daerah diharapkan dapat meningkatkan kesadaran pemerintah lokal akan alokasi sumber-sumber daya dan tidak bergantung kepada pemerintah pusat semata.

Dampak dari itu semua tentunya memiliki arti penting bagi pembangunan memandirian pemerintahan lokal, meski yang muncul berbagai agenda pemekaran wilayah namun itu semua merupakan ekses dari demokrasi yang tengah dibangun bangsa ini. Sangat kontras, ketika hegemoni negara yang dipraktikkan masa Orde Baru yang memarginalkan masyarakat lokal. Dengan demikian, diperlukan 
revitalisasi (diberi penguatan kembali) sehingga dapat diakomodasi dan diakses dalam pelaksanaan pembangunan.

Penguatan politik lokal atau identitas lokal harus dipahami sebagai salah satu kekuatan perekat integrasi nasional dan kekuatan yang memperlancar pembangunan. Revitalisasi identitas lokal dilakukan dalam tataran institusi, status, dan peran seperti Krama adat, lembaga dapat yang ditopang oleh aturan-aturan adat secara arif dan bijaksana. Jadi dapat dipahami bahwa dengan munculnya agenda pemekaran wilayah atas dasar asumsi-asumsi etnisitas yang lebih spesifik salah satu indikasi penguatan identitas terhadap wacana demokrasi lokal. Masyarakat Indonesia kaya akan identitas kelompok etnis, membutuhkan pemahaman yang serius dalam membangun kerangka interaksi politik yang toleran, yang dalam potensinya bisa memperkuat pluralisme (Abdilah, 2002). Sementara Giddens (2000) menjelaskan bahwa heterogenitas itu sendiri bukan merupakan suatu halangan. Dia merupakan bagian terpenting yang tak dapat dipisahkan dari arti "berbangsa dan bernegara" yang sesungguhnya.

Secara politik, bagaimana memanfaatkan pintu pemberian otonomi daerah tersebut sehingga menjadi sebuah jalan masuk bagi demokratisasi dan partisipasi rakyat, agar sejajar antara pemerintahan lokal dengan pertumbuhan otoritas pemerintah pusat yang melakukan stabilitas ekonomi, sosal dan politik serta meningkatkan partisipasi dalam program pembangunan (Mac Andrew, 1986). Oleh karena itu sebagaimana dikatakan Morfit, (1995) bahwa usaha yang dilakukan pemerintah pusat dalam menangani masalah yang ada di daerah adalah memperkuat posisi pemerintah daerah, ini semua terkait dengan desentralisasi yang dilakukan. Dengan demikian, akan menunjukkan betapa pentingnya peran pemerintah di aras lokal/daerah dalam melaksanakan pembangunan di daerahnya masing-masing.

Ketika konteks demokrasi lokal diwujudkan, maka semakin besar otonomi suatu pemerintah daerah, baik dalam arti kewenangan membuat keputusan maupun kewenangan keuangan, akan makin besar pula derajat proses politik yang khas lokal (local politics). Maka dengan kondisi tersebut, dapat disimpulkan yakni; Pertama, makin besar otonomi lokal yang diberikan, maka semakin besar pula proses demokratisasi dan politik lokal yang muncul di daerah. Kedua, semakin intesif peran elit masyarakat, maka semakin berkembang pula dinamika sosial politik di daerah yang bersangkutan. Ketiga, semakin dinamis proses demokratisasi maka semakin dinamis pula perkembangan politik lokal di daerah.

\section{KEBIJAKAN DANA PERIMBANGAN}

Davey (1988) mengatakan hubungan antara keuangan pusat dan daerah, prinsipnya lebih pada persoalan tentang pembagian kue kekuasaan. Terutama hak mengambil keputusan mengenai anggaran, yaitu bagaimana memperoleh dan membelanjakannya. Semua itu bertujuan untuk menggapai kesesuaian dengan peranan yang dimainkan pemerintah daerah (Devas, 1989:179). Dia juga mengidentifikasikan dua bentuk utama peranan pemerintah lokal/daerah yang 
masing-masing membutuhkan dukungan format kebijakan keuangan yang berbeda. Kedua peranan dan format kebijakan keuangan yang sesuai dengan masing-masing peranan tersebut yakni: Pertama, pandangan yang menekankan peranan pemerintah sebagai ungkapan kemauan dan indentitas masyarakat setempat. Pemerintah lokal/daerah merupakan wadah bagi penduduk setempat untuk mengemukakan aspirasinya sesuai dengan keinginan dan prioritas mereka. Kedua, pandangan yang menekankan peranan pemerintah lokal/daerah sebagai lembaga yang menyelenggarakan layanan-layanan publik dan sebagai alat untuk menebus biaya memberikan layanan yang bermanfaat untuk daerah.

Apa yang diungkapkan Davey dan Devas, intinya adalah menekankan pentingnya keseimbangan antara beban urusan yang menjadi tanggungjawab pemerintah lokal/daerah dan kewenangan finansialnya. Semakin luas urusan yang menjadi tanggungjawab pemerintah lokal/daerah, semakin besar pula kewenangan finansial yang dibutuhkannya. Sebagai konsekuensinya, seperti ditegaskan Hun Cho dan Meinardus (1996) "If decentralizacion of power is the aim, then logically decentralization public finances must go with it (Hun Cho dan Meinardus, 1996:175). Argumen tersebut, tentunya berdasar pada mendorong munculnya prinsip baru dalam politik pembiayaan desentralisasi. Prinsip baru ini tercemin pada adagium no mandate wihtout funding atau money follow functions menggantikan prinsip kuno yang dikemukan Wayong (Gaffar,dkk, 2002:189) yaitu functions follow money yang dinilai tidak realistik.

Undang-undang No. 32 Tahun 2004 tentang Pemerintahan Daerah pada dasarnya mengatur tentang pelaksanaan desentralisasi yang berlandaskan pada prinsip keseimbangan. Ditegaskan bahwa kewenangan pemerintahan yang diserahkan kepada daerah dalam rangka desentralisasi, harus disertai dengan penyerahan dan pengalihan pembiayaan, sarana dan prasarana, serta sumberdaya manusia sesuai dengan kewenangan yang diserahkan tersebut, meski dalam tataran implementasinya masih banyak mengundang kontroversi.

Gaffar, dkk (2002) menilai bahwa peraturan tentang masalah keuangan daerah yang ada masih bersifat setengah hati, karena titik beratnya masih tetap pada pembagian proporsi, bukan kepada pemberian kewenangan yang luas sebagaimana yang dinyatakan dalam UU No.22/1999 yang kemudian direvisi menjadi UU No.32/2004 (Gaffar, dkk, 2002:203). Uang memang merupakan sesuatu yang mutlak, namun uang bukan satu-satunya alat menggerakkan roda pemerintahan. Otonomi adalah kewenangan, dengan kewenangan, maka uang akan dapat dicari (Gaffar, dkk, 2002: 213).

Menyikapi persoalan dana perimbangan, dapat gali dari sisi kebijakan bagi hasil, pola bagi hasil masih dilakukan basis per basis pajak dan belum mencakup setiap sumber pendapatan pusat yang ada di daerah. Penekanan lebih besar pada bagi hasil sumberdaya alam (SDA), dinilai lebih menguntungkan daerah yang kaya SDA dan tidak menguntungkan daerah yang bukan penghasil kekayaan alam tersebut (Pratikno, 2002:66). Sementara sumber dana alokasi umum, meskipun didasarkan formula yang lebih objektif dan transparan, tetapi cenderung lebih 
mengutamakan pemerataan dan kurang memperhatikan sisi keadilan. Bahkan cenderung bersifat disinsentif karena tidak memperhitungkan kontribusi daerah kepada pendapatan pusat. Demikian pula pendekatan 25 persen dari pendapatan dalam negeri, belum dikembangkan untuk mencapai sufficiency pembiayaan daerah.

Jadi secara umum, transfer keuangan intra-pemerintahan hendaknya mampu mendorong peningkatan manajemen fiskal yang baik dan menghidari parktek yang tidak efisien (Shah, 1994:71). Bahkan mampu mengurangi beban perpajakan lokal yang relatif tinggi (Bailey, 1999:207). Upaya seperti ini akan dapat dilakukan pemerintah lokal/daerah, apabila pemerintah lokal/daerah memiliki kewenangan memadai di bidang pengelolaan sumberdaya ekonomi. Terutama kewenangan pemerintahan lokal/daerah dalam mengendalikan tarif pajak daerah (local tax power) (Bird dan Vaillancourt, 2000:49). Pemerintah lokal/daerah perlu memiliki dana memadai, sehingga memiliki fleksibilitas untuk lebih menekankan pada intensifikasi. Bahkan kemungkinan memberikan tax holiday demi merangsang investasi di daerahnya (Mardiasmo, 2002:153).

Melihat hasil studi de Mello dan Berenstein (Abed and Gupta, 2002:360) yang menunjukkan semakin besar bagian dana yang dibelanjakan daerah, semakin besar keterkaitan positif antara desentralisasi dan perwujudan governance. Agar tidak terjadi pelemahan upaya fiskal daerah, setiap desain perimbangan keuangan harus bersendikan elemen potensi kapasitas penerimaan daerah (Bird dan Vaillancourt, 2000:45). Misalnya di Spanyol, 25 persen dana perimbangan daerah dialokasikan menurut penerimaan pajak daerah dan 70 persen menurut jumlah penduduk. Sebagai perbandingan Denmark dan Swedia, Kanada dan Australia, secara eksplisit mengkalkulasikan dana perimbangan dengan mengasumsikan penerapan tarif pajak daerah menurut rata-rata nasional. Daerah yang menetapkan tarif pajak di atas rata-rata tarif pajak daerah, tidak diberi sanksi dengan pengurangan dana perimbangan. Sementara yang menerapkan tarif di bawah rata-rata, diberi insentif kenaikan dana perimbangan yang diterimanya.

Demikian pula, keuangan intra pemerintahan tidak seharusnya mengandung kompleksitas yang tidak perlu. Di semua negara, kompleksitas hunbungan fiskal antar pemerintahan tidak dapat dihindari dan biasanya tidak memuaskan bagi pihak-pihak yang terkait. Jika apa yang dikerjakan pusat adalah mesukseskan suatu tujuan khusus, dilakukan tanpa menambah kerumitan atas keuangan intrapemerintahan. Bilamana mungkin, transfer langsung ke kelompok masyarakat miskin lebih baik daripada transfer tidak langsung melalui daerah.

Kebijakan keuangan intra pemerintah, karenanya perlu dirancang lebih cermat. Devas (1988) mengemukakan tujuh kriteria dasar yang perlu diperhitungkan yaitu: simplicity (kesederhanaan, formula alokasi mudah dimengerti), adequacy (cukup untuk membiayai kebutuhan dasar daerah), elasticity (menyesuaikan diri terhadap inflasi, dil), stability and predictability (jumlah alokasi relatif stabil dan mudah diprediksi), equity (unsur pemerataan daerah), economic efficiency (menjamin efisiensi penggunaan dana), serta 
decentralization and local accountability (menjamin otonomi daerah dan akuntabilitas lokal) (Pratikno, 2002:61). Kriteria serupa ditegaskan oleh Shah (1994) yang mengemukakan sejumlah kriteri dasar yang perlu dipertimbangkan dalam merancang transfer keuangan intra-pemerintahan yaitu: autonomy, revenue adequacy, equity, predictability, efficiency (neutrality), simplicity, incentive, and safeguard of grantor's objectives (Shah, 1994:30).

Disamping PAD dan DAU/DAK dari Pemerintah Pusat, sumber dana pemerintah lokal/daerah lainnya yang potensial adalah "pinjaman daerah" (local borrowing). Berdasarkan undang-undang, daerah diberikan kewenangan melakukan pinjaman. Baik itu pinjaman pada pusat, bank komersial, dan institusi keuangan lainnya. Termasuk melakukan pinjaman ke luar negeri. Akan tetapi melalui peraturan No.107/2000, kewenangan ini oleh pusat diatur sangat ketat sekali yang pada akhirnya justru mempersulit kemungkinan pemerintah lokal/daerah untuk melakukan pinjaman.

Larangan pemerintah lokal/daerah untuk melakukan pinjaman ini, dapat menimbulkan kondisi kurang mendukung bagi percepatan perbaikan kinerja pemerintah lokal/daerah. Bahkan merupakan bentuk patronase lama untuk melindungi kinerja pemerintah lokal/daerah yang tidak efektif. Seperti dikemukakan Bird dan Vaillancourt (2000): "Pemberlakuan batasan utang untuk mencegah kesalahan fiskal pada pemda dapat berakibat buruk. Karena dapat membendung terjadinya sangsi pasar secara alamiah. Kreditur potensial pemerintah, dapat memiliki kemampuan dan motivasi untuk membuat evaluasi kemungkinan risiko pada uangnya.

Dari perspektif ini, kekhawatiran atas keteledoran pemerintah lokal/daerah yang dapat menyebabkan mereka terjebak dalam posisi sulit, merupakan contoh lain dari paternalisme yang tidak tepat atau keliru, yang umum terjadi pada pemerintah pusat dalam menghadapi kemungkinan tidak enaknya kehilangan kontrol akibat desentralisasi. Pemerintah lokal/daerah sulit berkinerja dengan baik jika mereka selalu diamankan dari kemungkinan berbuat salah dengan memberlakukan batasan yang sembarang atau jika mereka yakin bahwa pusat selalu siap memberikan bantuan. Jika pusat ingin menghidari permasalahan, dapat dilakukan dengan tidak memberikan subsidi atas utang pemerintah lokal/daerah dan merelakannya dililit utang terlalu banyak dan bangkrut seperti terjadi di Maroko" (Bird dan Vaillancourt, 2000:10).

Ilustrasi di atas tersebut, menandakan adanya sejumlah persoalan krusial yang ditengarai telah menjadi faktor penting guna mendorong otonomi seolah-olah identik dengan automoney. Meningkatkan PAD dengan cara menambah jenis dan meningkatkan tarif pajak/retribusi. Munculnya berbagai konflik perebutan sumber pendapatan antar pemerintahan. Seperti kengototan sejumlah Pemkab/Pemkot untuk mendapatkan bagi hasil lebih besar dari pajak kendaraan bermotor. Tuntutan pengalihan kewenangan pengelolaan uji kir kendaraan yang selama ini tangani Pemprov, hal serupa juga ditujukan pada sumber pajak yang selama ini dikuasai pusat. Seperti cukai rokok, bandara, pelabuhan, BUMN dan sebagainya. 


\section{PENUTUP}

Perimbangan keuangan pusat dan daerah merupangan suatu kebijakan yang berorientasi kepada terselenggaranya hubungan yang representatif dalam pemerintahan antara pusat dan daerah khususnya dalam rangka membentuk pemerintahan daerah yang mampu mengurus rumah tangganya dengan kemampuan sendiri secara berdayaguna dan berhasilguna.

Penyediaan sumber sumber pendanaan berdasarkan kewenangan pemerintah pusat, desentralisasi dan dekonsentrasi serta tugas pembantuan tersebut sebenarnya tidak hanya sekedar menyangkut masalah pembagian dana, namun lebih jauh merupakan pencerminan dari pembagian beban antara pusat dan daerah dalam melaksnakan tugas dan tanggung jawab pemerintahan Hubungan ini memiliki makna yang penting dalam mekanisme penyelenggaraan pemerintahan di daerah, mengingat dalam sistem pemerintahan negara yang berbentuk negara kesatuan, pusat adalah pusatnya daerah, dan daerah adalah daerahnya pusat.

Oleh karena itu dana perimbangan pusat untuk daerah tetap harus sebanding dengan yang diserap pusat dari daerah tersebut agar pemanfaatannya dapat memaksimalkan kesejahteraan rakyat di daerah. Tanpa ada good governance, dana tersebut tidak tepat sasaran dan tidak bisa menyejahterakan rakyat daerah dan akan menjadi ancaman terbesar bagi integrasi nasional karena hal itu cenderung menimbulkan kekecewaan daerah terhadap pusat hingga menyebabkan adanya konflik yang bersifat vertikal. Bila ancaman tersebut tidak segera diatasi, disintegrasi bangsa akan terus membayangi negeri ini, karena selain perjuangan dan gerakan ke arah otonomi daerah yang luas dan bertanggung jawab, hal itu merupakan kepentingan pemerintah lokal dalam memperjuangkan kemerdekaan bagi wilayahnya. Otonomi daerah yang dilaksanakan sesuai dengan prinsip-prinsip demokrasi, memberikan kewenangan yang luas, nyata dan bertanggung jawab kepada daerah secara proporsional yang diwujudkan dengan pengaturan, pembagian dan pemanfaatan sumberdaya nasional serta perimbangan keuangan pusat dan daerah.

Sebagaimana dalam penjelasan UU No.33 Tahun 2004 tentang perimbangan Keuangan Pemerintah pusat dan Daerah bahwa dalam rangka menyelenggarakan pemerintahan, pelayanan masyarakat dan pembangunan, maka pemerintah suatu negara pada hakekatnya mengemban tiga fungsi utama yaitu fungsi-fungsi alokasi, distribusi dan stabilisasi. Fungsi alokasi antara lain meliputi sumber-sumber ekonomi dalam bentuk barang dan jasa pelayanan masyarakat. Fungsi distribusi meliputi antara lain, pendapatan dan kekayan masyarakat, pemerataan pembangunan. Dan fungsi stabilisasi yang meliputi, antara lain, pertahanankeamanan, ekonomi dan moneter.

Pembagian ketiga fungsi tersebut adalah sangat penting sebagai landasan dalam penentuan dasar-dasar perimbangan keuangan antara pemerintah pusat dan daerah secara jelas dan tegas. Dengan adanya dana perimbangan yang 
meliputi bagi hasil pusat-daerah, dana alokasi umum dan dana alokasi khusus itu mencerminkan upaya dan asas keadilan perimbangan antara pusat dan daerah, disamping upaya dan asas pemerataan alokasi dana untuk berbagai kegiatan dan pembangunan di Daerah-daerah.

Kebijakan alokasi anggaran yang relatif meningkat besar ke arah daerahdaerah yang memiliki potensi SDM yang besar dan menguntungkan akan banyak merubah kemampuan daerah yang bersangkutan untuk membangun. Namun kondisi ini perlu diimbangi dengan dana perimbangan khususnya melalui dana alokasi umum (DAU), terutama bagi daerah yang miskin SDA dan potensi sumber pendapatan daerahnya agar tidak menimbulkan kesenjangan yang baru. Sehingga selain aspek keadilan dan pemerataan dalam sumber pembiayaan pembangunan juga diharapkan kemajuan dan pembangunan akan berjalan dengan berimbang antar daerah, sehingga ketimpangan pendapatan (dan pembangunan) akan menjadi semakin berkurang, dalam arti akan terjadi pemerataan antar daerah dalam pembangunan dan hasil-hasilnya.

\section{DAFTAR PUSTAKA}

Abdilah S., U. 2002. Politik Identitas Etnis: Pergulatan Tanda Tanpa Identitas, Magelang: Indonesiatera.

Abed, G. T., and G. Sanjeev. 2002. Governance, Corruption \& EconomicPerformance, IMF: Washington, D.C.

Bird, R. M. dan Vaillancourt, F. 2000. Desentralisasi Fiskal di Negara-negara Berkembang, PT. Gramedia Pustaka Utama: Jakarta.

Cho, C., and Meinardus. 1996. Local Autonomy and Local Finance, CLAHanyang University: South Korea.

Davey, K.J. 1988. Pembiayaan Pemerintah Daerah: Praktek-praktek Internasional dan Relevansinya Bagi Dunia Ketiga, UI Press: Jakarta.

Devas, N., dkk. 1989. Keuangan Pemerintah Daerah di Indonesia, UI-Press: Jakarta.

Gaffar, A., dkk. 2002. Otonomi Daerah dalam Negara Kesatuan, Pustaka Pelajar :Yogyakarta.

Gidden, A. 2000. Jalan Ketiga, Pembaruan Demokrasi Sosial, terj. Ketut Arya Mahardika, Jakarta: Gramedia Pustaka.

Gurr, T. 1993. Minorities, Nationalist, and Ethnipolitical Conflict Higley, John dan Richard Gunther (ed) (1992) Elite and Democratic Consolidation in Latin America abd Southern Europe, Cambridge: Cambridge University Press. 
Hardjosoekarto. 2002. Hubungan Pusat dan Daerah dalam Kerangka Kebijakan Desentralisasi dan Otonomi Daerah, Jurnal Administrasi Negara Vol. II No. 2.

Heinelt, H. and Wollmann. 2003. Local Politics Research In Germany: Developments and Characteristics In Comparative Perspective. London: Sage Publications.

Huntington, S. 2005. "Who Are We? America's Great Debate" Free Press, London.

Klinken, G. V. 2001. "The Maluku Wars: Bringing society back in," Indonesia 71 (April 2001), 1-26.

Mahi, Raksaka. 1998. "Prospek Desntralisasi di Indonesia ditinjau dari Pemerataan antar Daerah dan Peningkatan Efisiensi". Jakarta: LPEM FEUI.

Mardiasmo. 2002. Otonomi \& Manajemen Keuangan Daerah, ANDI: Yogyakarta.

Morfit, M. 1986. Strengthening the Capacities of Local Government : Policies and Constraints, in Mac Andrew (ed) Central Government and Development in Indonesia, Singapore: Oxford University Press.

Pratikno. 2002. Keuangan Daerah: Manajemen dan Kebijakan, MAP-UGM: Yogyakarta. (Pointers Kuliah).

Santosa, P. 2008. Administrasi Publik: Teori dan Aplikasi Good Governance. Bandung: PT. Refika Aditama.

Shah, A., and Qureshi, Z. 1994. Intergovernmental Fiscal Relations in Indonesia, The World Bank: Washington, D.C.

Sjamsudin, N. 1989. Integrasi Politik di Indonesia, Jakarta: Gramedia.

Surbakti, R. 1992. Memahami Ilmu Politik, Jakarta : Gramedia. 